\title{
Reverse Logistics Systems: Persepsi dan Harapan Konsumen
}

\author{
Farida Pulansari $^{*}$, Dwi Sukma Donoriyanto' ${ }^{1}$, Nisa Masruroh ${ }^{1}$
}

\begin{abstract}
Complaint is a signal that indicates important information directly by customers. Complaint will give valuable information to company to plan recovery strategies to maintain customer satisfaction and loyalty. Hence, electronic waste (E-waste) becomes a hot issue internationally, domestically and locally. There are many kind of regulations, strategy, methods or approach to minimize of E-waste. The goal of this research is design of house of reverse logistics (HRL) to understanding the customer needs and wants for reverse logistics (RL) implementation. This research adopted quality function deployment (QFD) method to construct the HRL. Differences among them are determination of the customer needs and wants. HRL insert five perspectives i.e. input, structure, process, output, and social and organization. In other hand, QFD only inserts consumer perspectives. The results showed the important factors of consumer dissatisfaction comes from: third-party services mechanism (20\%), collaboration RL system (collection centers, recycling centers, disposal center; 10\%), the standardization of servicing system $(10 \%)$.
\end{abstract}

Keywords: Reverse logistics, complaint, house of reverse logistics (HRL), quality function deployment (QFD).

\section{Pendahuluan}

Kepuasan konsumen adalah tingkat perasaan serta keinginan konsumen setelah membandingkan antara apa yang dia terima, persepsi dan harapan yang dikehendaki. Kepuasan konsumen adalah kebutuhan setiap perusahaan. Merawat, memelihara serta menjaga kepuasan konsumen merupakan faktor penting bagi kelangsungan hidup perusahaan, serta meningkatkan keunggulan dalam persaingan. Konsumen yang puas terhadap produk dan jasa pelayanan cenderung untuk membeli kembali produk dan menggunakan kembali jasa pada saat kebutuhan yang sama muncul kembali dikemudian hari atau yang disebut dengan loyalitas konsumen.

Ketidakpuasan konsumen identik dengan masalah komplain. Semakin banyak konsumen yang tidak puas, maka jumlah komplain akan mengalami peningkatan jumlahnya. Menurut Schegloff [1], komplain adalah fitur mendasar dari interaksi manusia, tidak hanya untuk tujuan praktis, tetapi juga dalam negosiasi keyakinan, nilai-nilai dan identitas. Definisi lain dikemukakan oleh Lee et al. [2], ia menyatakan bahwa komplain adalah signal berupa informasi penting yang berasal dari konsumen yang menggambarkan rasa ketidakpuasan. Disisi lain, komplain juga memberikan dampak positif bagi perusahaan.

\footnotetext{
1 Fakultas Teknologi Industri, Jurusan Teknik Industri, Universitas Pembangunan Nasional "Veteran" Jawa Timur, Jl. Rungkut Madya Surabaya 60294, Indonesia. Email: pulansari@gmail.com.

* Penulis korespondensi
}

Wagner [3] menyatakan bahwa jasa layanan komplain yang baik akan memberikan informasi yang berharga untuk peningkatan masalah distribusi dan performansi produk. Memahami karakteristik konsumen dan keinginan konsumen, perusahaan perlu penyesuaian strategi perusahaan untuk mempertahankan kepuasan serta loyalitas konsumen (Varela-Neira et al. [4]). Studi dari Filip [5] menyimpulkan bahwa perpindahan konsumen yang menguntungkan dapat dihindari apabila perusahaan mempertimbangkan bahwa komplain merupakan suatu indikator sebuah permasalahan yang memerlukan penyelesaian secara cepat. Jika jumlah komplain semakin meningkat, perusahaan perlu mencari cara yang efektif untuk kembali menciptakan peluang positif bagi investasinya serta meningkatkan performansi finansial (CambraFierro et al. [6]). Akhirnya, kesuksesan menjaga komplain akan menyelesaikan permasalahan dan membantu menjaga loyalitas konsumen (Lee et al. [2]).

Selanjutnya, masalah komplain konsumen ini akan dihubungkan dengan permasalahan lingkungan. Telah banyak peraturan baik skala internasional, domestik ataupun lokal yang telah dikeluarkan untuk meminimasi masalah lingkungan terutama E-waste. Beberapa aturan tersebut antara lain Directive 2002/96/EC yaitu Waste Electrical and Electronic Equipment (WEEE) dan Directive 2002/95/EC yaitu Restriction of Use of Certain Hazardous Substances in EEE (RoHS). Untuk di Indonesia, peraturan itu dituangkan ke dalam Buku IV, Peta Panduan (Road Map). Pengembangan 
Klaster Industri Prioritas Industri Elektronika dan Telematika Tahun 2010-2014 yang dikeluarkan oleh Departemen Perindustrian tahun 2009. Dalam buku tersebut dijelaskan bahwa setiap perusahaan yang bergerak dalam klaster industri elektronika wajib menggunakan komponen yang ramah lingkungan untuk meminimasi limbah $E$-waste. Aturan tersebut berlaku sampai jangka panjang yaitu tahun 2025. Salah satu metode yang mampu mengurangi jumlah limbah dan E-waste adalah reverse logistics (RL) dengan cara memanfaatkan secondary material. Komponen-komponen yang masih layak dan berfungsi akan digunakan lagi dalam pembuatan produk yang tentunya akan mengalami proses terlebih dahulu seperti remanufacturing, recycle, refurbish, recondition dan repair.

Dalam penelitiannya Buyukozkan dan Berkol [7] menyatakan bahwa QFD merupakan metode yang tepat untuk mengumpulkan sustainability requirement dalam supply chain sebagai alat untuk menganalisa competitive business environment. Penelitian lebih lanjut dilakukan oleh Buyukozkan dan Cifci [8], bahwa QFD mampu menerjemahkan keinginan konsumen ke dalam proses produksi dalam ruang lingkup sustainable supply chain (SSC). Disisi lain, Yu et al. [9] menyimpulkan QFD mampu mengidentifikasi 16 keinginan konsumen atas konsep modularity untuk menentukan end-of-life produk-produk elektronika konsumsi. Pendekatan fuzzy QFD akan dapat memperbaiki logistics process dan meningkatkan kepuasan konsumen [10]. Fuzzy QFD juga sangat efektif untuk mengetahui hubungan antara customer needs dan keandalan desain spesifikasi produk dalam konteks SCM [11].

Tujuan dari penelitian ini desain house of reverse logistics (HRL) yang akan menampung semua keluhan konsumen terhadap produk atau jasa yang telah dirasakan oleh konsumen atas implementasi RL guna meminimasi limbah beracun dan $E$-waste. Manfaat lain adalah HRL mampu mengenali karakteristik kebutuhan konsumen sehingga kepuasan serta loyalitas dapat tetap terjaga. HRL ini akan mengadopsi metode quality function deployment (QFD) lewat penyusunan house of quality (HOQ). Perbedaannya adalah penyusunan matriks WHATs. Dalam HRL matriks WHATs akan diisi oleh keinginan dan harapan konsumen atas implementasi RL.

\section{Metode Penelitian}

\section{Konsep Quality Function Deployment (QFD)}

Akao [12] mendefinisikan QFD adalah sebuah metode yang mengubah kebutuhan dan keinginan konsumen secara sistematis yang berguna untuk pengembangan kualitas produk, serta menggabungkan kebutuhan dan keinginan konsumen tersebut dalam produk dan jasa yang disediakan bagi konsumen. Cohen [13] mengusulkan bahwa QFD adalah metode perencanaan produk struktural dan inovasi yang memungkinkan tim inovasi untuk menentukan dengan jelas keinginan pelanggan dan kebutuhan, serta untuk mengevaluasi kemampuan masing-masing strategi untuk memenuhi kebutuhan konsumen. Hal yang sama dikemukakan oleh Dikmen et al. [14] yang menunjukkan bahwa QFD adalah salah satu teknik untuk menangani kebutuhan pelanggan dan harapan yang lebih sistematis untuk mencapai tujuan yang paling penting. Disisi lain, Govers [15] berpendapat bahwa metode QFD memiliki hubungan yang kuat antara pengembangan produk dan menghasilkan produk baru yang sesuai dengan harapan konsumen. QFD adalah suatu mekanisme untuk menerjemahkan suara pelanggan ke dalam bahasa teknik di seluruh berbagai tahapan inovasi produk baru [16].

Implementasi QFD memiliki banyak manfaat, baik dari sisi manufaktur maupun jasa. QFD dapat dianggap sebagai alat yang berguna untuk menghasilkan produk berkualitas tinggi dan mengurangi biaya dan waktu pengembangan (Bennera et al. [17]). Carnevalli dan Miguel [18] melaporkan bahwa QFD adalah metode yang didedikasikan untuk pemenuhan kebutuhan konsumen dan menerjemahkan ke dalam kegiatan manufaktur dan jasa. KuijtEvers et al. [19] juga menyimpulkan bahwa QFD merupakan metode desain yang efektif untuk menerjemahkan kebutuhan pelanggan menjadi karakteristik rekayasa dengan mengintegrasikan kebutuhan ergonomis dan mengaplikasikannya ke dalam produk sesuai dengan keinginan dan kebutuhan konsumen. Berdasarkan beberapa manfaat di atas dapat disimpulkan bahwa: (1) QFD merupakan suatu alat yang dapat menerjemahkan kebutuhan konsumen dan merekayasa respon teknis untuk pemenuhan kebutuhan itu sendiri. (2) QFD dapat membantu tim menangani kebutuhan konsumen berdasarkan persepsi dan harapan, bukan berdasarkan intuisi atau penalaran yang tidak didasarkan atas data yang akurat. (3) QFD bersifat fleksibel yang artinya setiap respon teknis yang ada, masih dapat dilakukan pengembangan dan modifikasi sesuai dengan kebutuhan dan kemampuan perusahaan.

\section{Konsep Reverse Logistics (RL)}

Dalam studinya Pokharel dan Mutha [20] menyimpulkan bahwa penelitian reverse logistics (RL) dimulai sekitar tahun 1960an. Topik-topik penelitian RL berkembang sesuai dengan permasalahan yang 
dihadapi pada saat itu. RL memiliki definisi sebagai suatu sistem yang memiliki perencanaan, pemrosesan, implementasi dan pengontrolan yang efektif baik berupa bahan baku maupun barang jadi yang kesemuanya terintegrasi dengan informasi mengenai jumlah permintaan pasar dan berusaha menggunakan bahan buangan tersebut untuk dikonsumsi kembali menjadi sebuah produk (Pokharel dan Mutha [20], Bernon et al. [21], Lambert et al. [22]).

Banyak manfaat yang dapat dirasakan dari implementasi RL. Moore [23] menyatakan bahwa survei yang telah dilakukan terhadap 125 perusahaan didapatkan total pendapatan sekitar $50-70 \%$ dari proses remanufacturing. Studi dari Kumar dan Putnam [24] menghasilkan kesimpulan bahwa implikasi RL berdampak pada penghematan energi sebesar $74 \%$, bahan baku mentah $90 \%$, limbah pertambangan sebesar $97 \%$, emisi udara $88 \%$, serta penggunaan air sebesar $76 \%$. Perusahaan yang mengimplementasikan sistem RL akan mendapatkan penghematan sebesar $\$ 43$ milyar (Genchev [25]). Wrap [26] menyatakan bahwa implementasi RL akan berdampak pada minimasi jumlah limbah, biaya, dampak karbon, kesehatan serta keamanan. Akhirnya Giri dan Sharma [27] menyimpulkan bahwa program product recovery yang merupakan salah satu capaian RL akan berdampak pada penurunan life cycle dari produk-produk yang sering dipakai.

\section{Metodologi}

Tujuan dari penelitian ini adalah desain house of reverse logistics (HRL). Proses desain HRL ini akan mengadopsi metode HOQ dalam QFD. Perbedaan antara HRL dan HOQ ini adalah pada matriks WHATs. Dalam HRL, matriks WHATs akan diisi dengan customer requirements yang telah disesuaikan dengan persepsi dan harapan konsumen atas implementasi RL. Adapun langkah-langkah penelitian terlihat pada Gambar 1 yaitu: (1) Penentuan customer requirement dalam matriks WHATs sesuai dengan persepsi dan harapan konsumen atas implementasi RL (2) Penentuan technical response matrix (HOWs) untuk menanggapi penilaian, keluhan serta komplain konsumen yang didasarkan pada kemampuan perusahaan baik dari segi visi dan misi, modal, kemampuan sumber daya manusia, peraturan pemerintah dan tuntutan baik secara lokal, domestik maupun internasional. (3) Penentuan technical correlations antar technical response dan relationships. (4) Penentuan planning matrix yang terdiri dari importance to customers, customer satisfaction performance, goal, improvement ratio, sales point, raw weight dan normalized raw weight. (5) Penentuan technical matrix yang terdiri dari contribution, normalized contribution dan target/rank.

\section{Hasil dan Pembahasan}

\section{Desain House of Reverse Logistics (HRL)}

Desain HRL ini didasarkan pada penelitian Pokharel dan Mutha [20] yang telah meneliti semua penelitian RL. Dalam studinya, pengelompokan penelitian RL mulai tahun 1960 sampai tahun 2008 dibagi menjadi 4 perspektif yaitu RL input, RL process, RL structure dan RL output. Topik yang dibahas dalam RL input antara lain: pemilihan raw material, safety stock, forecast strategy dan inventory systems (Minner [28], Pati et al. [29], Donghong et al. [30], Peng et al. [31]). Tujuan yang akan dicapai adalah bagaimana mempersiapkan material baik yang berasal dari virgin material ataupun secondary material. Pada RL process, permasalahan yang sering dibahas adalah mengenai disassembly product, production process mechanism, remanufacturing, recycle, recondition, dan refurbish (Kleber et al. [32], Hu et al. [33], Dobos [34], Yalabik [35]). Disisi lain, permasalahan seperti kapasitas produksi dan desain infrastruktur telah dibahas oleh Shih [36], Bayindir et al. [37], dan $\mathrm{Qu}$ dan William [38]. Adapun hal yang ingin diselesaikan dalam RL process ini adalah bagaimana perencanaan proses produksi yang efektif dan efisien yang dapat menghasilkan produk yang memiliki kualitas baik. Pengelompokan ketiga yaitu RL structure. Dalam kelompok ini, topik yang dibahas adalah location and allocation planning, networking (Kara et al. [39]; Neto et al. [40]; Lee dan Dong [41] Kenne et al. [42]). Sedangkan untuk RL output, hal-hal yang sering dibahas adalah pricing, revenue management, product competition, dan waste management (Mitra [43]; Liang et al. [44]; Vadde et al. [45]). Tujuan yang ingin dicapai adalah bagaimana produk yang telah dihasilkan dapat bersaing baik dari segi harga, kualitas dan servis.

Kelompok baru yang diusulkan adalah RL social and organization. Pengelompokan ini didasarkan pada banyaknya penelitian RL yang belum dikelompokkan pada keempat kelompok RL diatas. Tujuan dari kelompok ini adalah bagaimana perusahaan mampu membangun RL system thinking baik di kalangan decision maker maupun karyawan pada umumnya. Tujuan lain yang ingin dicapai adalah RL social \& organization akan digunakan sebagai alat untuk memperbaiki strategi perusahaan untuk memenangkan persaingan usaha. Disamping itu tanggung jawab perusahaan kepada masyarakat atas implementasi RL yang telah dilakukan, khususnya masalah waste yang dihasilkan. Disisi lain, dengan memperhatikan masalah customer needs and wants pada RL social \& organization akan dapat meningkatkan profit, kepuasan dan loyalitas konsumen perusahaan. Adapun topik- 


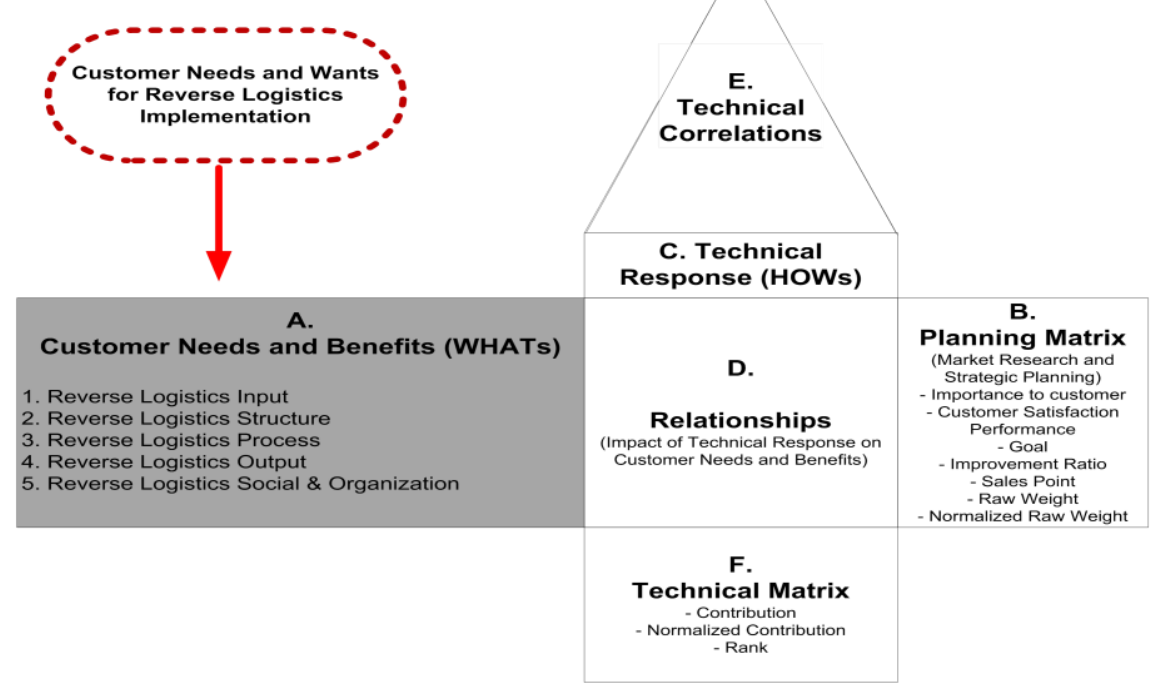

Gambar 1. Langkah-langkah desain HRL

topik tersebut antara lain: reclaiming mechanism, stakeholders, organizational slack, market competition, corporate social responsibility, service center \& third parties services dan decision model and process (Richey et al. [46], Alvarex-Gil et al. [47], Kumar dan Putnam [24], Cheng dan Lee [48], Azadi dan Saen [49], Guarnieri et al. [50]; Rezaei [51], Vahabzadeh et al. [52], Agrawal et al. [53], Tavana et al. [54]).

\section{Penentuan Customer Needs and Wants}

Penelitian ini telah dilaksanakan pada satu perusahaan elektronik terbesar di Jawa Timur yang menjual produk dengan merk " $\mathrm{X}$ ". Penentuan customer needs and wants didasarkan pada jumlah komplain terbanyak dari konsumen yang ditujukan pada perusahaan langsung, service center dan third parties services. Disamping itu, peneliti juga melakukan tinjauan langsung ke beberapa distribution center (DC) yang menjual produk merk "X" untuk mengetahui persepsi dan harapan konsumen terhadap performance dan kualitas produk. Tinjauan langsung ini berfungsi untuk melihat konsistensi data ketidakpuasan konsumen yang sudah terkumpul di beberapa service center dengan kondisi nyata di lapangan. Beberapa kriteria customer needs and wants atas implementasi RL (Tabel 1) didapatkan dari data yang berhasil dikumpulkan oleh peneliti yang bekerja sama dengan pihak manajemen perusahaan.

\section{Penentuan Technical Response}

Setelah mengetahui kriteria customer needs and wants yang selama ini menjadi penyebab ketidakpuasan konsumen, maka langkah selanjutnya adalah penentuan technical response. Technical response adalah respon teknis yang diberikan oleh perusahaan untuk meminimasi ketidakpuasan yang dirasakan oleh perusahaan. Penentuan technical response, didasarkan atas kemampuan perusahaan atas dasar visi dan misi perusahaan, strategi perusahaan, modal yang dimiliki, dan kemampuan sumber daya manusia. Disamping itu, peraturan pemerintah menjadi hal penting dalam penentuan technical response.

Tabel 1. Identifikasi customer needs and wants atas implementasi RL

\begin{tabular}{|c|c|}
\hline RL Input & $\begin{array}{l}\text { 1. Kategori raw material berasal dari } \\
\text { sumber daya alam asli, komponen bekas } \\
\text { atau komponen daur ulang } \\
\text { 2. Aktivitas pihak reverse logistics } \\
\text { outsourcing }\end{array}$ \\
\hline RL Structure & $\begin{array}{l}\text { 1. Lokasi pengembalian produk (returned } \\
\text { used product) } \\
\text { 2. Mekanisme proses pengumpulan, } \\
\text { pemeriksaan dan pengembalian produk } \\
\text { 3. Integrasi antara proses manufacturing } \\
\text { dan remanufacturing }\end{array}$ \\
\hline RL Process & $\begin{array}{l}\text { 1. Mekanisme pembongkaran produk } \\
\text { (disassembly) } \\
\text { 2. Sistem informasi manajemen reverse } \\
\text { logistics } \\
\text { 3. Mekanisme penanganan komponen- } \\
\text { komponen yang heterogen } \\
\text { 4. Mekanisme penjadwalan untuk } \\
\text { komponen yang baru datang, proses } \\
\text { penyimpanan dan proses pembuangan } \\
\text { 5. Perbaikan dan layanan purna jual }\end{array}$ \\
\hline RL Output & $\begin{array}{l}\text { 1. Sistem penentuan harga untuk produk } \\
\text { remanufaktur } \\
\text { 2. Integrasi sistem pemeliharaan kepuasan } \\
\text { konsumen } \\
\text { 3. Peningkatan kualitas layanan }\end{array}$ \\
\hline $\begin{array}{l}R L \text { Social \& } \\
\text { Organization }\end{array}$ & $\begin{array}{l}\text { 1. Kebijakan dan strategi perusahaan } \\
\text { 2. Sistem pemasaran yang terintegrasi } \\
\text { 3. Kebijakan pengembalian produk } \\
\text { (returned policy) }\end{array}$ \\
\hline
\end{tabular}


Table 2. Penentuan technical response

1. Peraturan perundang undangan

2. Dukungan teknologi dalam proses produksi

3. Kolaborasi dengan para pelaku RL (collection center, recycle center, disposal center)

4. Mekanisme integrasi dengan 3PL (third parties services)

5. Keseimbangan antara forward dan reverse logistics systems

6. Sistem PPIC (production planning and inventory control) untuk virgin material dan secondary material

7. Struktur dan desain produk (konsep modularity)

8. Mekanisme pengaturan komunikasi dengan para pelaku RL

9. Sistem informasi manajemen untuk para pelaku RL

10. Sistem inventory control

11. Kebijakan produk bergaransi (warranty product claim)

12. Lokasi dan jumlah service center

13. Penentuan harga untuk produk remanufactured

14. Strategi peningkatan kualitas layanan konsumen

15. Desain teknologi informasi untuk komunikasi dengan konsumen

16. Standarisasi mekanisme servis produk

17. Manajemen peningkatan kemampuan SDM

18. Sistem pemasaran untuk produk remanufactured

19. Desain produk didasarkan atas karakteristik konsumen

Sebelum melakukan tahap selanjutnya, data ketidakpuasan konsumen yang berada di service center mulai diklasifikasikan menjadi 5 kelompok. Pemilihan tujuh service center sebagai tempat pengumpulan data dikarenakan pertimbangan beberapa hal antara lain: memiliki jumlah komplain/ketidakpuasan tertinggi, memiliki demand/permintaan produk yang tinggi dan lokasi serta berdirinya service center lebih dari 5 tahun. Adapun lokasi service center tersebuat adalah PRI Surabaya, ASCUD. Duta Bina Teknik (Gresik), ASC-Windra Service (Malang), ASC-Mandiri Service (Mojokerto), ASC-Adhi Citra Elektronik (Krian), ASC-NR Elektronik (Pasuruan) dan ASC-Yohasa Service (Surabaya). Terdapat perbedaan antara PRI dan ASC. PRI adalah service center resmi perusahaan, sedangkan ASC adalah third parties services. Setelah melakukan uji statistik yang meliputi uji validitas dan reliabilitas, maka hasil yang didapatkan adalah valid dengan nilai lebih besar dari $r$ tabel yaitu 0,4555 dengan $\mathrm{DF}=15$ dan tingkat kepercayaan sebesar 95\%. Sedangkan untuk uji reliabilitas didapatkan nilai Cronbach's Alpha sebesar 0,891. Dengan demikian data dapat disimpulkan reliabel.

Langkah-langkah selanjutnya yang harus dilakukan adalah penentuan technical correlations yaitu technical response dan relationships, penentuan planning matrix yang terdiri dari importance to customers, customer satisfaction performance, goal, improvement ratio, sales point, raw weight dan normalized raw weight serta penentuan technical matrix yang terdiri dari contribution, normalized contribution dan target/rank. Adapun simbol-simbol yang digunakan antara lain: $0=$ tidak ada hubungan, 1=kemungkinan ada hubungan, 3=hubungan sedang dan 9=hubungan sangat kuat. Disisi lain, planning matrix berisi beberapa informasi tentang: (1) Quantitative market data, yang mengindikasikan pentingnya antara keinginan dari konsumen (customer needs and wants) untuk memenuhi kepuasan dari konsumen dan perbaikan strategi dari perusahaan. (2) Strategic goal setting untuk produk atau jasa. (3) Perhitungan peringkat atau urutan dari customer needs and wants.

Dari customer needs and wants yang telah terkumpul, proses selanjutnya adalah manajemen perusahaan menentukan technical response untuk menanggapi setiap keluhan yang ada. Dari setiap technical response yang telah dibentuk maka akan saling mempengaruhi antara satu dengan yang lainnya. Proses inilah yang disebut dengan technical correlation. Setiap kebijakan yang dikeluarkan oleh perusahaan akan membawa dampak positif dan negatif. Hal ini disebabkan karena kebijakan yang dibentuk berkaitan dengan masalah modal, tenaga kerja, strategi, perubahan infrastruktur serta waktu yang tidak singkat. Sehingga apabila salah satu technical response akan ditingkatkan kualitasnya, maka tidak menutup kemungkinan technical response lainnya akan menurun kualitasnya. Ada kalanya peningkatan yang dilakukan akan berdampak meningkatnya kualitas technical response lainnya.

Proses selanjutnya adalah penentuan matriks relationship. Hubungan antara relationship ini ditentukan oleh perusahaan berdasarkan analisa korelasi yang dihasilkan oleh keluhan konsumen apabila tidak ditindaklanjuti oleh perusahaan. Angka 9 menunjukkan bahwa customer needs and wants memiliki pengaruh yang signifikan terhadap kepuasan serta loyalitas konsumen itu sendiri. Selanjutnya angka 3, 1 dan 0 menunjukkan tingkatan pengaruh yang dihasilkan. Semakin kecil nilainya memiliki arti bahwa sangat kecil pengaruh yang dihasilkan atau tidak ada pengaruh sama sekali antara pengaruh customer needs and wants dengan technical response yang telah dibentuk. Langkah berikutnya adalah penentuan planning matrix yang dilakukan oleh perusahaan. Dalam hal ini perhitungannya didasarkan dari jumlah keluhan tertinggi. Semakin tinggi jumlah keluhan terhadap salah satu atribut dalam customer needs and wants, maka akan berdampak pada tingginya nilai planning matrix itu sendiri. Sehingga perusahaan harus memprioritaskan atribut tersebut, apabila tidak ingin konsumen berpindah ke produk lainnya. 
Tabel 3. Penentuan target

\begin{tabular}{lccc}
\hline \multicolumn{1}{c}{ Technical response } & Contribution & $\begin{array}{c}\text { Normalized } \\
\text { contribution }\end{array}$ & Targets \\
\hline Peraturan perundang undangan & 0,67 & 0,03928 & 10 \\
Dukungan teknologi dalam proses produksi & 1,12 & 0,06572 & 4 \\
Kolaborasi dengan para pelaku RL (collection center, recycle center, & 1,91 & 0,11270 & 2 \\
disposal center) & 3,45 & 0,20298 & 1 \\
Mekanisme integrasi dengan 3PL (third parties services) & 0,58 & 0,03419 & 11 \\
Keseimbangan antara forward dan reverse logistics systems & 1,10 & 0,06456 & 6 \\
Sistem PPIC (production planning and inventory control) untuk virgin & 0,38 & 0,02211 & 15 \\
material dan secondary material & 1,04 & 0,06131 & 7 \\
Struktur dan desain produk (konsep modularity) & 1,11 & 5 \\
Mekanisme pengaturan komunikasi dengan para pelaku RL & 0,36 & 0,06551 & 16 \\
Sistem informasi manajemen untuk para pelaku RL & 0,16 & 0,00958 & 17 \\
Sistem inventory control & 0,82 & 0,04812 & 9 \\
Kebijakan produk bergaransi (warranty product claim) & 0,56 & 0,03317 & 12 \\
Lokasi dan jumlah service center & 0,56 & 0,03317 & 13 \\
Penentuan harga untuk produk remanufactured & 0,19 & 0,01106 & 15 \\
Strategi peningkatan kualitas layanan konsumen & 1,74 & 0,10270 & 3 \\
Desain teknologi informasi untuk komunikasi dengan konsumen & 0,72 & 0,04229 & 8 \\
Standarisasi mekanisme servis produk & 0,45 & 0,02654 & 14 \\
Manajemen peningkatan kemampuan SDM & 0,06 & 0,00369 & 18 \\
Sistem pemasaran untuk produk remanufactured & & \\
Desain produk didasarkan atas karakteristik konsumen & &
\end{tabular}

Tabel 3 merupakan perhitungan akhir untuk menentukan prioritas dari customer needs and wants dan technical response yang harus diprioritaskan terlebih dahulu karena memiliki dampak rasa ketidakpuasan konsumen yang tinggi.

Dari Tabel 3 dapat dijelaskan bahwa prioritas utama perusahaan adalah mekanisme integrasi dengan 3PL (third parties services) dengan nilai sebesar 0,203. Prioritas kedua adalah Kolaborasi dengan para pelaku RL (collection center, recycle center, disposal center) dengan nilai sebesar 0,113. Prioritas ketiga yang harus mendapatkan perhatian dari perusahaan adalah Standarisasi mekanisme servis produk dengan nilai sebesar 0,103. Penentuan tingkatan prioritas ini dimaksudkan untuk memberikan ruang pada perusahaan untuk melakukan perbaikan langsung kepada permasalahan yang ada. Perbaikan yang langsung pada akar permasalahan akan dapat mengurangi rasa ketidakpuasan konsumen.

\section{Simpulan}

Berdasarkan hasil penelitian dan studi kasus yang telah dilakukan, persepsi dan harapan konsumen merupakan salah faktor penting dalam keberhasilan sebuah perusahaan. Semakin puas konsumen maka mengindikasikan perusahaan dapat diterima dengan baik, baik dari segi kualitas produk dan layanan yang diberikan. Persepsi dan harapan konsumen atas implementasi reverse logistics perlu dikaji untuk mengetahui sejauh mana kepuasan yang dirasakan.
Desain HRL ini bertujuan untuk mengetahui customer needs and wants atas implementasi RL yang dilakukan oleh perusahaan. Tujuan lain yang ingin dicapai adalah perusahaan dapat selalu memperbaiki strategi perusahaan untuk meningkatkan profit serta kepuasan dan loyalitas konsumen. Dari studi kasus yang telah dilakukan di PT. X didapatkan beberapa customer needs and wants yang memiliki kontribusi tertingi terhadap rasa ketidakpuasan konsumen. Customer needs and wants ini perlu mendapatkan perhatian khusus dari perusahaan karena berdampak pada kepuasan serta loyalitas konsumen. Adapun tiga customer needs and wants yang memiliki nilai kontribusi tertinggi antara lain: mekanisme integrasi dengan 3PL (third parties services) (20,29\%), kolaborasi dengan para pelaku RL (collection center, recycle center, disposal center) $(11,27 \%)$, standarisasi mekanisme servis produk (10,27\%), dukungan teknologi dalam proses produksi (6,57\%), dan sistem informasi manajemen untuk para pelaku RL (6,55\%).

\section{Ucapan Terima Kasih}

Penulis mengucapkan banyak terima kasih kepada Direktorat Penelitian dan Pengabdian Masyarakat, Direktorat Jenderal Pendidikan Tinggi (DIKTI) atas diterimanya Program Hibah Penelitian Tahun Anggaran 2016 (Lanjutan) Nomor: SPP/12/UN.63.8/ LIT/III/2016 tanggal 02 Maret 2016. Adapun Hibah Penelitian Hibah Bersaing yang diterima dengan judul "Desain Framework of Reverse Logistics Maturity Level Menuju Kondisi Environmental Friendly, Green Product, Eco Efficiency dan Government Control \& Policy pada Klaster Industri Elektronika Konsumsi”. 


\section{Daftar Pustaka}

1. Schegloff, E.A., On Complainability, Social Problems, 52(4), 2005, pp. 449-476.

2. Lee, C.H., Wang, Y.H., and Trappey, A.J.C., Ontology-based Reasoning for the Intelligent Handling of Customer Complaints, Computers \& Industrial Engineering, 84(June), 2015, pp. 144-155.

3. Wagner, W., Managing Customer Complaints in Distribution, International Journal of Physical Distribution \& Logistics Management, 24(4), 1994, pp. 11-17.

4. Varela-Neira, C., Vasquez-Casielles, R., and Iglesias, V., Explaining Customer Satisfaction with Complaint Handling, International Journal of Bank Marketing, 28(2), 2010, pp. 88-112.

5. Filip, A., Complaint Management: A Customer Satisfaction Learning Process, Procedia - Social and Behavioral Sciences, 93(October), 2013, pp. 271-275.

6. Cambra-Fierro, J., Melero, I., and Sese, F.J., Managing Complaints to Improve Customer Profitability, Journal of Retailing, 91 (1), 2015, pp. 109-124.

7. Buyukozkan, G., and Berkol, C., Design of Sustainable Supply Chain using an Integrated Analytic Network Process and Goal Programming Approarch in Quality Function Deployment, Expert Systems with Applications, 38(11), 2011, pp. 13731-13748.

8. Buyukozkan, G., and Cifci, G., An Integrated QFD Framework with Multiple Formated and Incomplete Preferences: A Sustainable Supply Chain Application, Applied Soft Computing, 13(9), pp. 3931-3941.

9. Yu, S., Yang, Q., and $\mathrm{Xu}, \mathrm{X}$., Incorporating Quality Function Deployment with Modularity for the End-of-Life of a Product Family, Journal of Cleaner Production, 87(January), pp. 423430.

10. Bottani, E., and Rizzi, A., Strategic Management of Logistics Service: A Fuzzy QFD Approach, International Journal of Production Economics, 103(2), pp. 585-599.

11. Sohn, S.Y., and Choi, I.S., Fuzzy QFD for Supply Chain Management with Reliability Consideration, Reliability Engineering and Systems Safety, 72(3), pp. 327-334.

12. Akao, Y., Quality Function Deployement: Integrating Customer Requirement into Product Design, Portland, Productivity Press, 1990.

13. Cohen, L., Quality Function Deployement: How to Make QFD Work for You, Massachusetts, Addition-Wesley Publishing Company, 1995.
14. Dikmen, I., Birgonul, M.T., and Kiziltas, S., Strategic Use of Quality Function Deployment (QFD) in the Construction Industry, Building and Environment, 40(2), 2005, pp. 245-255.

15. Govers, C.P.M., What and How about Quality Function Deployment (QFD), International Journal of Production Economics, 46-47, 1996, pp. $575-585$.

16. Kim, D.H., and Kim, K.J., Robustness Indices and Robust Prioritization in QFD, Expert Systems with Applications, 36(2), 2009, pp. 2651-2658.

17. Bennera, M., Linnemanna, A.R., Jongena, W. M.F., and Folstara, P., Quality Function Deployment (QFD) - Can It be Used to Develop Food Products? Food Quality and Preference, 14(4), 2003, pp. 327-339.

18. Carnevalli, J.A., and Miguel, P.C., Review, Analysis and Classification of the Literature on QFD-Types of Research, Difficulties and Benefits, International Journal of Production Economics, 114(2), 2008, pp. 737-754.

19. Kuijt-Evers, L.F.M., Morel, K.P.N., Eikelenberg, N. L. W., and P.Vink., Application of the QFD as a Design Approach to Ensure Comfort in Using Hand Tools: Can the Design Team Complete the House of Quality Appropriately? Applied Ergonomics, 40(3), 2009, pp. 519-526.

20. Pokharel, S., and Mutha, A., Perspectives in Reverse Logistics: A Review. Resources, Conservation and Recycling, 53(4), 2009, pp. 175-182.

21. Bernon, M., Rossi, S., and Cullen, J., Retail Reverse Logistics: A Call and Grounding Framework for Research, International Journal of Physical Distribution \& Logistics Management, 41, 2011, pp. 484-510.

22. Lambert, S., Riopel, D., and Abdul-Kader, W., A Reverse Logistics Decisions Conceptual Framework, Computers \& Industrial Engineering, 61(3), 2011, pp. 561-581.

23. Moore, R., Reverse Logistics-the Least Used. White Paper, UPS Supply Chain Solutions, 2005.

24. Kumar, S., and Putnam, V., Crandle to Crandle: Reverse Logistics Strategies and Opportunities Across Three Industry Sectors, International Journal of Production Economics, 115(2), 2008, pp. 305-315.

25. Genchev, S.E., Reverse Logistics Program Design: A Company Study, Business Horison, 52(2), 2009, pp. 139-148.

26. Wrap, Case Study: Reverse Logistics for Plasterboard A Unique Operation to Manage the Delivery of Plasterboard and Backhaul the Offcuts and Wastage, Oxon. www.wrap.org.uk/ construction, 2010. 
27. Giri, B.C., and Sharma, S., Optimizing a Closedloop Supply Chain with Manufacturing Defects and Quality Dependent Return Rate, Journal of Manufacturing Systems, 35, 2015, pp. 92-111.

28. Minner, S., Strategic Safety Stocks in Reverse Logistics Supply Chains, International Journal of Production Economics, 71(1-3), 2001, pp. 417428.

29. Pati, R.K., Vrat, P., and Kumar, P., Economic Analysis of Paper Recycling vis-a' -vis Wood as Raw Material, International Journal of Production Economics, 103, 2006, pp. 489-508.

30. Donghong, Y., Yujie, T., and Hui, L., The Research on the Inventory Cost Control of Return Reverse Logistics, International Conference on Information Management, Innovation Management and Industrial Engineering, IEEE, Taipei, Taiwan, 2008.

31. Peng, B., Pan, Y., and Pan, F., Study on Inventory Control Model of Reverse Logistics for Products in Declining Periods, International Conference on Electronics Commerce and Business Intelligence, IEEE, Beijing, China, 2009.

32. Kleber, R., Minner, S., and Gudrun, K., A Continuous Time inventory Model for a Product Recovery System with Multiple Options, International Journal of Production Economics, 79(2), 2009, pp. 121-141.

33. Hu, T.L., Sheu, J. B., and Huang, K.H., A Reverse Logistics Cost Minimization Model for the Treatment of Hazardous Wastes, Transportation Research Part E, 38(6), 2002, pp. 457473.

34. Dobos, I., Optimal Production-Inventory Strategies for a HMMS-type Reverse Logistics System, International Journal of Production Economics, 81-82, 2003, pp. 351-360.

35. Yalabik, B., Petruzzi, N.C., and Chhajed, D., An Integrated Product Returns Model with Logistics and Marketing Coordination. European Journal of Operational Research, 161(1), 2005, pp. 162-182.

36. Shih, L.H., Reverse Logistics System Planning for Recycling Electrical Appliances and Computers in Taiwan, Resources, Conservation and Recycling, 32(1), 2001, pp. 55-72.

37. Bayındır, Z.P., Erkip, N., and Güllü, R., Assessing the Benefits of Remanufacturing Option under One-way Substitution and Capacity Constraint, Computers \& Operations Research, 34(2), 2007, pp. 487-514.

38. Qu, X., and Williams, J.A.S., An Analytical Model for Reverse Automotive Production Planning and Pricing, European Journal of Operational Research, 190(3), 2008, pp. 756767.
39. Kara, S., Rugrungruang, F., and Kaebernick, H., Simulation Modelling of Reverse Logistics Networks, International Journal of Production Economics, 106(1), 2007, pp. 61-69.

40. Neto, J.Q.F., Bloemhof-Ruwaard, J.M., Nunen, J.A.E.E.V., and Heck, E.V., Designing and Evaluating Sustainable Logistics Networks, International Journal of Production Economics, 111(2), 2008, pp. 195-208.

41. Lee, D.H., and Dong, M., Dynamic Network Design for Reverse Logistics Operations under Uncertainty, Transportation Research Part E, 45(1), 2009, pp. 61-71.

42. Kenne', J.P., Dejaz, P., and Gharb, A., Production Planning of a Hybrid ManufacturingRemanufacturing System, International Journal of Production Economics, 135(1), 2012, pp. 8193.

43. Mitra, S., Revenue Management for Remanufactured Products, Omega, 35(5), 2007, pp. $553-$ 562.

44. Liang, Y., Pokharel, S., and Lim, G.H., Pricing Used Products for Remanufacturing, European Journal of Operational Research, 193(2), 2009, pp. 390-395.

45. Vadde, S., Zeid A., and Kamarthi, S.V., Pricing Decisions in a Multi-criteria Setting for Product Recovery Facilities, Omega, 39(2), 2011, pp. 186-193.

46. Richey, R.G, Chen, H., Genchev, S.E., and Daugherty, P.J., Developing Effective Reverse Logistics Programs, Industrial Marketing Management, 34(8), 2005, pp. 830 - 840.

47. Álvarez-Gil, M.J., Berrone, P., Husillos, F.J., and Lado, N., Reverse Logistics, Stakeholders' Influence, Organizational Slack, and Managers' Posture, Journal of Business Research, 60(5), 2007, pp. 463-473.

48. Cheng, Y.H., and Lee, F., Outsourcing Reverse Logistics of High-tech Manufacturingfirms by Using a Systematic Decision-making Approach: TFT-LCD Sector in Taiwan, Industrial Marketing Management, 39(7), 2010, pp. 1111-1119.

49. Azadi, M., and Saen, R.F., Comprehensive Performance Measurement and Causal-effect Decision Making Model for Reverse Logistics Enterprise, Computers \& Industrial Engineering, 68, 2011, pp. 87-103.

50. Guarnieri, P., Sobreiro, V.A., Nagano, M.S., and Serrano, A.L.M., The Challenge of Selecting and Evaluating Third-party Reverse Logistics Providers in a Multicriteria Perspective: A Brazilian Case, Journal of Cleaner Production, 96, 2015, pp. 209-219.

51. Rezaei, J., A Systematic Review of Multi-Criteria Decision-making Applications in Reverse Logistics, Transportation Research Procedia, 10, 2015, pp. 766-776. 
52. Vahabzadeh, A.H., Asiaei, A., and Zailani, S., Green Decision-making Model in Reverse Logistics using Fuzzy-Vikor Method, Resources, Conservation and Recycling, 103, 2015, pp. 125-138.

53. Agrawal, S., Singh, R.K., and Murtaza, Q., Outsourcing Decisions in Reverse Logistics:
Sustainable Balanced Scorecard and Graph Theoretic Approach, Resources, Conservation and Recycling, 108, 2016, pp. 41-53.

54. Tavana, M., Zareinejad, M., Caprio, D.D., and Kaviani, M.A., An Integrated Intuitionistic Fuzzy AHP and SWOT Method for Outsourcing Reverse Logistics, Applied Soft Computing, 40, 2016, pp. 544-557. 